\title{
The significance of computational modelling in murine cardiac ventricular cells
}

\author{
Semahat S Demir \\ Joint Graduate Program in Biomedical Engineering, The University of Memphis and The University of Tennessee Health \\ Science Center, Memphis, TN, USA; Adjunct Faculty of Graduate School of Science and Engineering, Işık University, \\ Maslak, Istanbul, Turkey
}

\begin{abstract}
Five decades of histological, electrophysiological, pharmacological and biochemical investigations exist, but relatively little is known regarding the ionic mechanisms underlying the action potential variations in the ventricle associated with healthy and disease conditions. The computational modelling in murine ventricular myocytes can complement our knowledge of the experimental data and provide us with more quantitative descriptions in understanding different conditions related to normal and disease conditions. This paper initially reviews the theoretical modelling for cardiac ventricular action potentials of various species and the related experimental work. It then focuses on the progress of computational modelling of cardiac ventricular cells for normal, diabetic and spontaneously hypertensive rats. Also presented is the recent modelling efforts of the action potential in mouse ventricular cells. The computational insights gained into the ionic mechanisms in rodents will enhance our understanding of the heart and provide us with new knowledge for future studies to treat cardiac diseases in children and adults.
\end{abstract}

Keywords: mathematical modelling, ventricular myocytes, cell membrane, simulations, model development

\section{Introduction}

The rat and mouse animal models have been well characterised in terms of cardiac mechanics, biochemistry and basic electrophysiology. The murine ventricular action potential (Figure 1) still continues to be a topic of considerable interest in cardiac electrophysiology and mathematical modelling for several reasons. First, the murine ventricular action potential is shorter and lacks a prominent plateau phase compared with those in human, dog, guinea pig and rabbit. Second, mathematical modelling for ventricular cells has been done the most in guinea pig and relatively less in rat, mouse and rabbit. Furthermore, the differences in ventricular membrane ionic currents, especially outward $\mathrm{K}^{+}$currents, in different species have very important practical implications. Different drugs are known to affect different ionic currents and to change action potential waveforms in different mammalian heart preparations under normal conditions of ageing and gender, and also under various pathophysiological conditions.

Heart diseases are often associated with action potential prolongation. $\mathrm{K}^{+}$currents are key determinants of cardiac action potential duration (APD) and thus of prime targets in controlling repolarisation. For all these reasons, there is great interest in defining the ionic and molecular basis of mouse cardiac currents and especially $\mathrm{K}^{+}$currents. A number of different laboratories are collecting and presenting experimental data on ventricular myocytes; however, there is not much mathematical model development for murine ventricular cells using all of these available data. Biophysically detailed models for both rat and mouse ventricular myocytes are needed to utilise the data, to be used as predictive tools and to enhance our understanding of the living systems at the cellular levels in electrophysiology.

\section{Cardiac ventricular action potential and its ionic basis}

Normal cardiac action potentials can be classified into two broad categories: (1) those that are self-oscillatory in nature, such as pacemaker cells; and (2) those that need an external stimulus in order to be evoked, such as atrial or ventricular cells. An extraordinary diversity in the action potential configurations can be seen in different regions of the heart. The ventricular tissue, in particular, displays a wide variety of action potential waveforms. These include pacemaker

\footnotetext{
Correspondence: Semahat S Demir, Department of Biomedical Engineering, The University of Memphis, Memphis, TN 38I52-3210, USA; tel + I 901678 3170; fax + I 901678 528I; email

sdemir@memphis.edu
} 
a

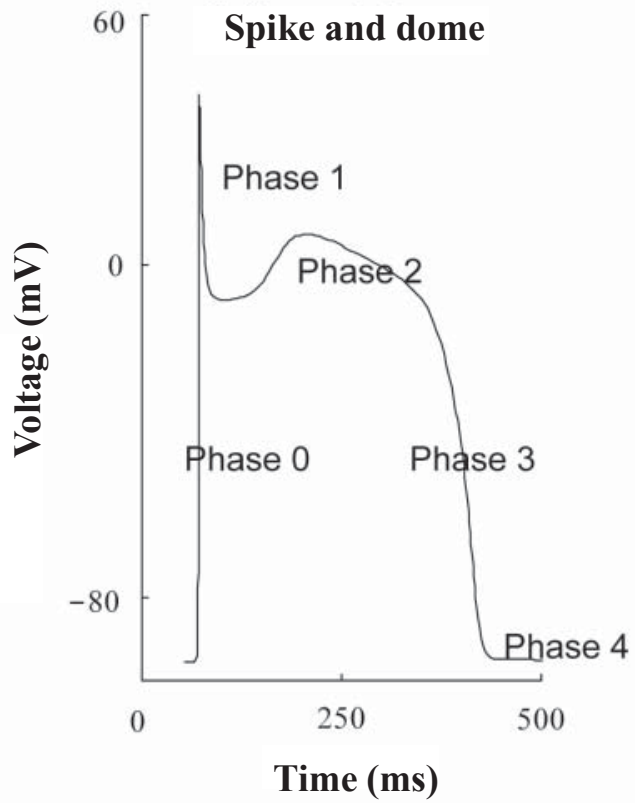

b

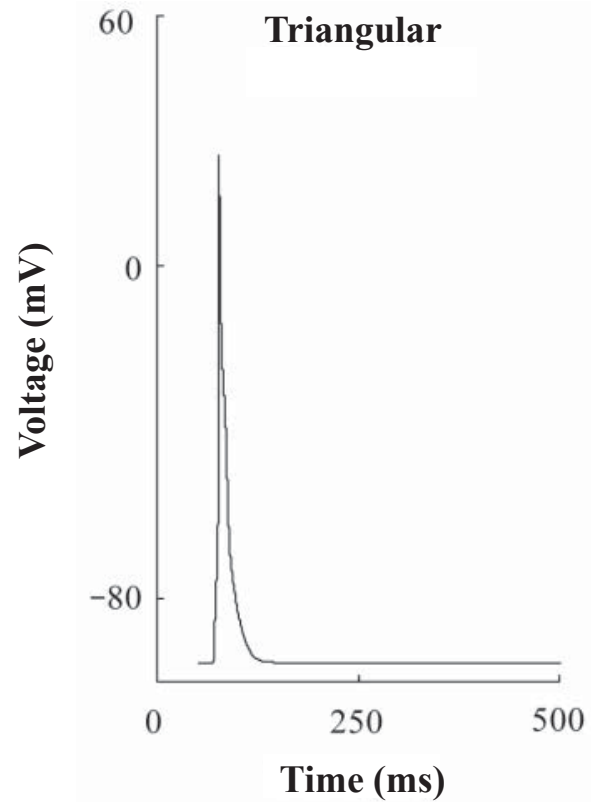

Figure I The simulated cardiac action potential waveforms of the dog (Demir et al 1996) (a) and the rat (Pandit et al 200I) (b) ventricular cells.

potentials in purkinje cells, and disparate APDs and morphologies in cells from the epicardial, mid-myocardial and endocardial layers of the ventricle. The ventricular action potential has been studied more frequently than other representative cardiac membrane potentials because ventricular arrhythmias are believed to constitute the majority of reportedly fatal incidences of cardiac arrhythmias (Spooner and Rosen 2000).

A typical ventricular action potential in higher mammals, such as canine and human, consists of four distinct phases (see Figure 1a). Phase 0 corresponds to a rapid depolarisation or upstroke of the membrane action potential. Phase 1 is the initial rapid repolarisation and is followed by phase 2 , which constitutes the action potential plateau. Phase 3 represents the final repolarisation, which allows the ventricular cell to return to its resting state in phase 4 . In addition to its morphological features, ventricular action potentials are commonly measured experimentally to determine its characteristics. These include the resting membrane potential $\left(V_{\text {rest }}\right)$, the peak overshoot value, which is the maximum positive value achieved during the initial phase 0 depolarisation, the maximum upstroke velocity $\left(\mathrm{d} V / \mathrm{d} t_{\max }\right)$ that occurs during phase 0 , and the APDs measured when the action potentials have repolarised to $50 \%$ and $90 \%$ of their final repolarisation value, also called $\mathrm{APD}_{50}$ and $\mathrm{APD}_{90}$, respectively. One or more of these characteristics is usually altered in the setting of a pathophysiological condition and helps to quantify the differences between normal and abnormal action potentials.
The temporal changes in a typical ventricular action potential configuration, ie depolarisation followed by a repolarisation, are governed by the movement of different ions, such as $\mathrm{Na}^{+}, \mathrm{K}^{+}$and $\mathrm{Ca}^{2+}$, across the sarcolemma. These ions are usually transported between the intracellular and the extracellular spaces by means of carrier proteins and channel proteins embedded in the cardiac membrane. These proteins form the passive (ion channel-mediated and carrier-mediated) and active (carrier proteins such as the pumps and exchanger) transporters of the cell membrane. The ion channels, the pumps and exchanger are the major ionic currents that form an action potential in mathematical representations. A summary of these currents that are present in a typical cardiac ventricular cell and the role of the currents in action potential generation are summarised in Table 1. The ventricular action potential is the result of a delicate 'balance' of the inward currents, outward ion currents and the active transporters (pump and exchanger).

\section{Review of theoretical (mathematical modelling) research}

Patch clamp experiments carried out in enzymatically isolated ventricular myocytes, along with molecular biology techniques, have provided a wealth of detailed information regarding the subcellular nature (ionic channels and their putative molecular correlates) of the ventricular action potential. However, there is growing recognition that it is 
Table I Major membrane currents underlying a typical cardiac ventricular action potential

\begin{tabular}{|c|c|c|}
\hline Membrane currents & Description & Role in action potential \\
\hline \multicolumn{3}{|c|}{ Inward ionic currents } \\
\hline $\mathrm{I}_{\mathrm{Na}}$ & $\mathrm{Na}^{+}$current & $\begin{array}{l}\text { Initial depolarisation of } \\
\text { action potential }\end{array}$ \\
\hline $\mathrm{I}_{\mathrm{CaL}}$ & L-type $\mathrm{Ca}^{2+}$ current & $\begin{array}{l}\text { Maintains plateau phase } \\
\text { of action potential }\end{array}$ \\
\hline $\mathrm{I}_{\mathrm{CaT}}$ & T-type $\mathrm{Ca}^{2+}$ current & $\begin{array}{l}\text { Present in the late } \\
\text { plateau phase }\end{array}$ \\
\hline \multicolumn{3}{|c|}{ Outward ionic currents } \\
\hline$I_{t}$ & $\begin{array}{l}\mathrm{Ca}^{2+} \text {-independent } \\
\text { transient outward } \\
\mathrm{K}^{+} \text {current }\end{array}$ & $\begin{array}{l}\text { Responsible for early } \\
\text { repolarisation }\end{array}$ \\
\hline $\mathrm{I}_{\mathrm{Kr}}, \mathrm{I}_{\mathrm{Ks}}$ & $\begin{array}{l}\text { Rapid and slow } \\
\text { delayed } \mathrm{K}^{+} \text {rectifier } \\
\text { currents }\end{array}$ & $\begin{array}{l}\text { Aids repolarisation } \\
\text { during plateau }\end{array}$ \\
\hline $\mathrm{I}_{\mathrm{ss}}, \mathrm{I}_{\mathrm{Kslow}}$ & $\begin{array}{l}\text { Slow inactivating } \\
\mathrm{K}^{+} \text {currents }\end{array}$ & Aids late repolarisation \\
\hline $\mathrm{I}_{\mathrm{K} 1}$ & $\begin{array}{l}\text { Inward rectifier } \\
\mathrm{K}^{+} \text {current }\end{array}$ & $\begin{array}{l}\text { Late repolarisation, } \\
\text { helps establish rest } \\
\text { potential }\end{array}$ \\
\hline \multicolumn{3}{|l|}{ Other currents } \\
\hline $\mathrm{I}_{\mathrm{NaCa}}$ & $\begin{array}{l}\mathrm{Na}^{+}-\mathrm{Ca}^{2+} \text { exchanger } \\
\text { current }\end{array}$ & Late depolarisation \\
\hline $\mathrm{I}_{\mathrm{NaK}}$ & $\mathrm{Na}^{+}-\mathrm{K}^{+}$pump current & Late repolarisation \\
\hline
\end{tabular}

also important to understand the complex nonlinear interactions between the ionic milieu of the cardiac cell that ultimately influence the action potential (Winslow et al 2000). This has led to the development over the last decade of sophisticated mathematical models, which attempt to theoretically reconstruct the ventricular action potential by formulating equations for the ionic currents postulated to give rise to the membrane potential (Rudy 2000). The equations are usually based on the pioneering work of Hodgkin and Huxley (1952), wherein an ionic current is described by a set of nonlinear differential equations, and the parameters within these equations are constrained by experimental data obtained via voltage-clamp experiments in ventricular myocytes.

After the first models of the mammalian cells by Noble (1962), Beeler and Reuter (1977), and Drouhard and Roberge (1987), mathematical models that simulate the cardiac action potentials in ventricular cells from different species, such as canine (Winslow et al 1999; Fox et al 2002), guinea pig (Luo and Rudy 1991, 1994; Nordin 1993; Zeng et al 1995; Noble et al 1998), human (Priebe and Beuckelmann 1998; Ten Tusscher et al 2004), frog (Riemer et al 1998) and rabbit (Puglisi and Bers 2001), have been published during the past decade. These models have proven to be useful didactic tools in research and have also quantified the important functional differences in the action potential properties between different species. Additionally, these models have also provided valuable, semi-quantitative insights into the diverse ionic mechanisms underlying the normal/abnormal action potential behaviour in different animal models. This is important because it is not always possible to make precise experimental measurements regarding the contribution of a particular ionic mechanism to an aberrant action potential. The simulation results from these cardiac models have helped in planning for future experimental studies and also in making predictions in cases where suitable technology is unavailable (or not developed) to make direct experimental measurements (such as visualising the transmural activity within the ventricular wall). It is believed that these models, in addition to experimental studies, will play an increasingly important role in the design and development of future drugs and devices (Members of the Sicilian Gambit 2001). An additional and important feature of these ventricular models has been their ability to simulate intracellular $\mathrm{Ca}^{2+}$ transient $\left(\left[\mathrm{Ca}^{2+}\right]_{\mathrm{i}}\right)$ (Winslow et al 2000). This has enabled the models to incorporate an essential physiological aspect, since there exists a feedback mechanism between the APD and the intracellular calcium $\left[\mathrm{Ca}^{2+}\right]_{\mathrm{i}}$. APD is known to influence the amplitude of $\left[\mathrm{Ca}^{2+}\right]_{\mathrm{i}}$ in ventricular cells (Bouchard et al 1995), and $\left[\mathrm{Ca}^{2+}\right]_{\mathrm{i}}$ in turn influences the action potential waveform by $\mathrm{Ca}^{2+}$-induced $\mathrm{Ca}^{2+}$ inactivation of $\mathrm{I}_{\mathrm{CaL}}$ and by determining the peak magnitude of $\mathrm{I}_{\mathrm{NaCa}}$ (Bers 2001). Further model development of the ion channels that are based on transitions between states has pioneered to describe ion channel kinetics better and has started to link genetic basis of disease processes to electrophysiological function (Clancy and Rudy 1999).

The above-mentioned mathematical models of human, dog, guinea pig, rabbit and frog provide a good basis for the understanding of the ionic mechanisms responsible for the generation of the cardiac action potential. However, there are significant differences in the action potential waveforms and their corresponding properties between different species. The unique nature of the rat cardiac action potential, coupled with the available experimental data for the ionic mechanisms involved in the genesis of the action potential in isolated rat myocytes, provided the motivation to develop the first detailed mathematical model of the rat ventricular action potential. An adult male rat ventricular myocyte model was constructed (Pandit et al 2001) and utilised to 
study the ionic basis underlying the action potential heterogeneity in the adult rat left ventricle. Determining the electrophysiological differences between epicardial and endocardial cells has provided important insights into the role of the long-lasting $\mathrm{Ca}^{2+}$ current $\left(\mathrm{I}_{\mathrm{CaL}}\right)$, the $\mathrm{Ca}^{2+}-$ independent transient outward $\mathrm{K}^{+}$current $\left(\mathrm{I}_{t}\right)$ and the steadystate outward $\mathrm{K}^{+}$current $\left(\mathrm{I}_{\mathrm{ss}}\right)$. This ventricular cell model has been used to investigate the ionic mechanisms that underlie altered electrophysiological characteristics associated with the short-term model of streptozotocininduced type I diabetic rats (Pandit et al 2003) and spontaneously hypertensive rats (Padmala and Demir 2003). Thus, these model simulations reproduce a variety of experimental results and provide quantitative insights into the functioning of ionic mechanisms underlying the regional heterogeneity in the adult rat ventricle.

\section{Review of significance of experimental research in murine ventricular cells}

The ventricular cell models of dog, guinea pig, human and rabbit described in the previous section have been mainly used to simulate the so-called 'spike and dome' configurations for action potentials (Figure 1a) commonly observed in ventricular cells from higher mammalian species (Antzelevitch et al 1999). However, no mathematical model has been published to represent the murine (rat or mouse) cardiac action potential until the rat ventricular cell (Pandit et al 2001). The murine ventricular action potentials have a much shorter APD (typically, $\mathrm{APD}_{90}$ is less than $100 \mathrm{~ms}$ ) and lack a well defined plateau phase (ie they are 'triangular' in shape) (Watanabe et al 1983; Clark et al 1993; Fiset et al 1997) (see Figure 1b). A comparison of the experimentally recorded ionic currents underlying action potentials in rat/ mouse and other mammalian ventricular cells shows that they display markedly different amplitudes and timedependent behaviour. In fact, despite the similarity of action potential waveforms in rat and mouse, the underlying nature of the repolarising $\mathrm{K}^{+}$currents is different (Fiset et al 1997). Thus, the unique action potential characteristics, and the lack of models to quantify these membrane properties, provide the motivation to develop the rat and mouse ventricular cell models. However, the mere absence of a mathematical model for a particular species cannot alone justify its development. The other justification in this case is provided by the widespread use of the murine cardio- vascular system for the investigation of the cellular and molecular physiology of compromised cardiovascular function (Chien 2000).

It is not surprising that mouse and rat hearts are now extensively used in mechanical, biochemical, molecular/ genetic and electrophysiological studies. Transgenic mouse and rat models provide powerful tools for the investigation of cellular and molecular physiology of the heart and cardiovascular abnormalities.

The rat has been extensively utilised to characterise the cellular and ionic basis of abnormal cardiac repolarisation and excitation-contraction (EC) coupling process in a variety of pathophysiological conditions such as hypertrophy (Bryant et al 1999), myocardial infarction (Qin et al 1996), thyroid dysfunction (Shimoni et al 1995) and diabetes (Shimoni et al 1994). Rat is also the preferred model of choice in cardiac drug development and screening (Budden et al 1980; Cheung et al 1993). Recent advances in transgene and gene targeting technology has enabled the manipulation of the rat and mouse genomes, which are now increasingly employed to study both inherited and acquired cardiac disorders (Franz et al 1997; Gehrmann and Berul 2000). The rat genetic model of hypertrophy (Lijnen and Petrov 1999) and mouse genetic models of cardiac arrhythmias (Keating and Sanguinetti 2001), cardiomyopathies (Seidman JG and Seidman C 2001) and heart failure (Minamisawa et al 1999) have been developed. These genetic models have provided valuable insights into the molecular/functional basis of altered action potential profiles and impaired EC coupling in compromised myocytes.

The pace of developments in genetic technology continues unabated, and genetically modified mouse models of human cardiovascular disease have progressed from transgenesis and gene targeting to gene rescue (Chien 2001). However, the progress in genetic technology has far outstripped the currently available capability to analyse the phenotype(s) resulting from genetic manipulations (Robbins 2000). As an example, more than 20 mouse models with altered $\mathrm{K}^{+}$channel expression/functioning have been generated using dominant-negative and targeted deletion approaches (Nerbonne et al 2001). The phenotypic consequences resulting from the manipulations of these $\mathrm{K}^{+}$ channels have sometimes been unexpected, and the sheer volume of data generated has confounded their interpretation and will require more than simple intuition (Nerbonne et al 2001). Quantitative approaches offer a unique promise in this regard. Under these circumstances, computational 
models of the rat and/or mouse ventricular cells have the potential to serve as useful integrative and predictive research tools, and test existing experimental hypotheses. Any discrepancy between the model results and experiments can be used to ask new questions and to motivate new experiments, or to refine the models themselves, thus setting the stage for a useful and iterative feedback process between modelling studies and experiments.

\section{Review of experimental research in potassium current diversity and action potential waveforms in mouse ventricular myocytes}

Recent advances in genetic engineering have resulted in the creation of an expanding number of mouse models in an attempt to mimic cardiac arrhythmia disorders in humans (Gehrmann and Berul 2000). These include mouse models of congenital long QT syndrome (LQTS) (Barry et al 1998), dilated cardiomyopathy (Minamisawa et al 1999) and abnormal cardiac conduction (Jalife et al 1999; NguyenTran et al 2000). Molecular cloning has revealed an even greater potential for generating voltage-gated potassium channel diversity, than was expected based on electrophysiology, with the identification of many potassium channel pore-forming $\alpha$ and accessory subunits in heart. A variety of experimental approaches have been exploited to probe the relationship(s) between these subunits and the functional voltage-gated potassium channels in myocardial cells. Additionally, the genetic susceptibility of cardiac arrhythmias has been probed in mice by selective knockouts of pore-forming $\alpha$ and/or accessory $\beta$ subunits of $\mathrm{K}^{+}$ channels (Kuo et al 2001; Nerbonne et al 2001). The mouse model has also been used to study the gender-specific differences in cardiac repolarisation (Trepanier-Boulay et al 2001). A common factor associated with all these studies has been the variation in the APD profile (due to disease, gender differences or gene knockouts). It is therefore essential to have a detailed understanding of the ionic mechanisms controlling the alterations in cardiac repolarisation in mouse ventricular myocytes.

Experimental studies indicate that the patterns of action potential waveforms are somewhat similar in rodents (rat or mouse), although the APD is shorter in mouse, and the complement of the $\mathrm{K}^{+}$currents underlying the cardiac repolarisation in mouse are also different than those in rat (Gussak et al 2000; Nerbonne 2001). The cardiac repolarisation in rat is controlled by two distinct depolarisation-activated $\mathrm{K}^{+}$currents: the $\mathrm{Ca}^{2+}$-independent transient outward $\mathrm{K}^{+}$current $\left(\mathrm{I}_{\mathrm{t}}\right)$ and the steady-state outward $\mathrm{K}^{+}$current $\left(\mathrm{I}_{\mathrm{ss}}\right)$ (Clark et al 1993; Shimoni et al 1995). In mouse ventricular myocytes, an additional current, the 4APsensitive (at concentrations less than $100 \mu \mathrm{mol} / \mathrm{L}$ ), slowly inactivating, delayed rectifier $\mathrm{K}^{+}$current $\left(\mathrm{I}_{\mathrm{Kslow}}\right)$, has been deemed to play an important role (Fiset et al 1997; Zhou et al 1998). The properties of the depolarisation-activated $\mathrm{K}^{+}$ currents have been well characterised in rat (Clark et al 1993; Shimoni et al 1998) and mouse (Zhou et al 1998; Xu et al 1999) and appear to be significantly different. It is therefore interesting to investigate in computational modelling whether the reported differences in the properties of the depolarisation-activated $\mathrm{K}^{+}$currents can account for the dissimilar nature of the action potential configurations observed in rats and mice.

\section{Computational modelling of the rat and mouse ventricular action potentials}

Our goal has been to unify different experimental data, develop biophysically detailed models for the rat and mouse ventricular cells and determine the underlying ionic channels responsible for differences in cardiac action potential variations in rats and mice under normal and diseased conditions.

We have developed a computational model for the rat cardiac ventricular cell based on electrophysiology data. Our control model (Pandit et al 2001) represents the bioelectric activity in the left ventricular cells in adult male rats. We have formulated the differences in the membrane properties within the left ventricle (LV) to simulate the action potential variations of the endocardial and epicardial cells. We also built a right ventricular cell model from our control model to investigate ionic mechanisms in the right ventricle (RV) of diabetic rats (Pandit et al 2003). Our right ventricular cell model was also the template for us to develop a mouse ventricular cell model by utilising experimental data.

The left and right ventricular cell models for the rat consist of a Hodgkin-Huxley-type membrane model, which is described by the membrane capacitance and various ionic channels: the fast $\mathrm{Na}^{+}$current $\left(\mathrm{I}_{\mathrm{Na}}\right)$; the long-lasting $\mathrm{Ca}^{2+}$ current $\left(\mathrm{I}_{\mathrm{CaL}}\right)$; the $4 \mathrm{AP}$-sensitive, $\mathrm{Ca}^{2+}$-independent transient outward $\mathrm{K}^{+}$current $\left(\mathrm{I}_{\mathrm{t}}\right)$; the steady-state outward $\mathrm{K}^{+}$current $\left(\mathrm{I}_{\mathrm{ss}}\right)$; the inward rectifier $\mathrm{K}^{+}$current $\left(\mathrm{I}_{\mathrm{K} 1}\right)$; the hyper- 
polarisation-activated current $\left(\mathrm{I}_{\mathrm{f}}\right)$; the linear background current $\left(\mathrm{I}_{\mathrm{B}}\right)$; the $\mathrm{Na}^{+} / \mathrm{Ca}^{2+}$ ion exchanger $\left(\mathrm{I}_{\mathrm{NaCa}}\right)$; and the $\mathrm{Na}^{+} /$ $\mathrm{K}^{+}\left(\mathrm{I}_{\mathrm{NaK}}\right)$ and $\mathrm{Ca}^{2+}$ membrane $\left(\mathrm{I}_{\mathrm{CaP}}\right)$ pumps, which are experimentally observed in rat ventricular cells.

The mouse ventricular cell model was constructed by using the rat right ventricular cell model as the template. We developed a mouse LV apex cell (Pandit 2002; Damaraju 2003) by adding the 4AP-sensitive, slowly inactivating, delayed rectifier $\mathrm{K}^{+}$current $\left(\mathrm{I}_{\text {Kslow }}\right)$ based on the data of Fiset et al (1997), and by reformulating $I_{t}$ and $I_{s s}$ based on experiments performed by Zhou et al (1998) and Xu et al (1999) in mice.

The important results of our simulation studies are as follows:

1. The action potential heterogeneity (Figure 2 ) in the adult rat $\mathrm{LV}$ is mainly due to the changes in the density and recovery kinetics of $\mathrm{I}_{\mathrm{t}}$ and due to the altered density of $\mathrm{I}_{\mathrm{Na}}$ (Pandit et al 2001).

2. The right ventricular cell model can be developed from the left ventricular cell model by changing the densities of $\mathrm{I}_{\mathrm{t}}, \mathrm{I}_{\mathrm{ss}}, \mathrm{I}_{\mathrm{CaL}}$ and $\mathrm{I}_{\mathrm{NaK}}$ based on experimental data.

3. The changes in the density and the reactivation kinetics of $I_{t}$ can account for the action potential prolongation differences in RV myocytes of diabetic (type I, shortterm) rats (Pandit et al 2003) (Figure 3) and LV myocytes of spontaneously hypertensive rats (Padmala and Demir 2003) (Figure 4).

4. The presence of $\mathrm{I}_{\mathrm{Kslow}}$ in mouse is one of the main factors contributing to the faster rate of repolarisation seen in mouse compared with rat (Figure 5). This faster rate of repolarisation matches well with the experimental data of Ward et al (1997) in rat and of Fiset et al (1997) in mouse.

5. The rat epicardial and endocardial ventricular cell models were more rate-sensitive than the mouse ventricular cell model, and these simulation data match the experimental data well.

In conclusion, the mathematical modelling study of murine ventricular myocytes complements our knowledge of the biophysical data with simulation data and provides us with quantitative descriptions to understand the ionic currents underlying the cardiac action potential variations in different species. This kind of computational work will enhance our understanding of the ionic mechanisms that contribute to the cardiac action potential variation in normal and diseased animals, and will provide us with better treatments for diseases in humans.

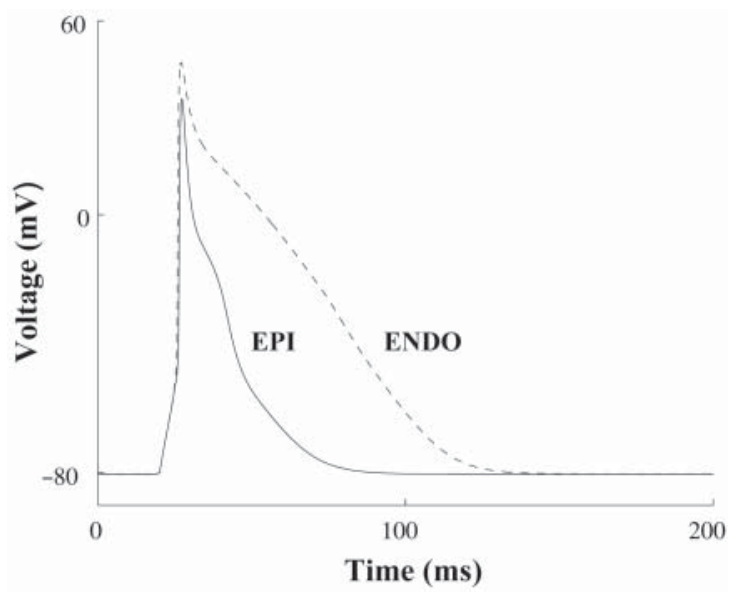

Figure 2 Simulated action potentials of the rat left ventricular epicardial (EPI) and endocardial (ENDO) cells.

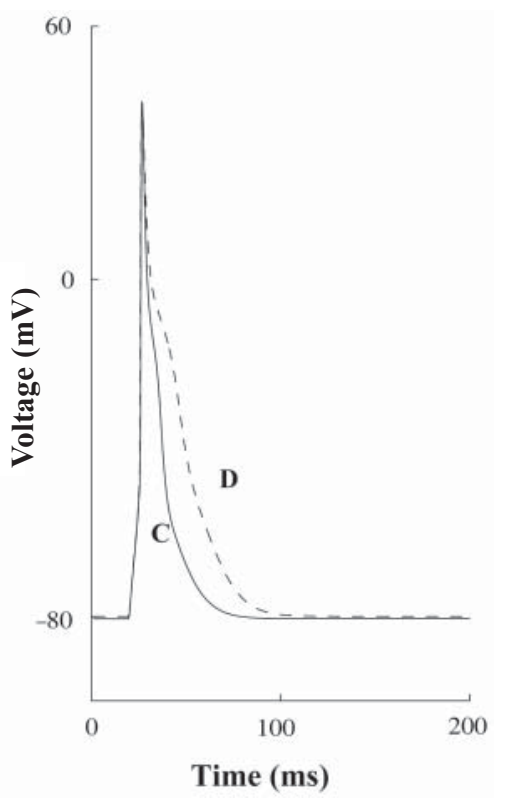

Figure 3 Action potential waveforms of the right ventricular cell models in control $(C)$ and diabetic $(D)$ rats.

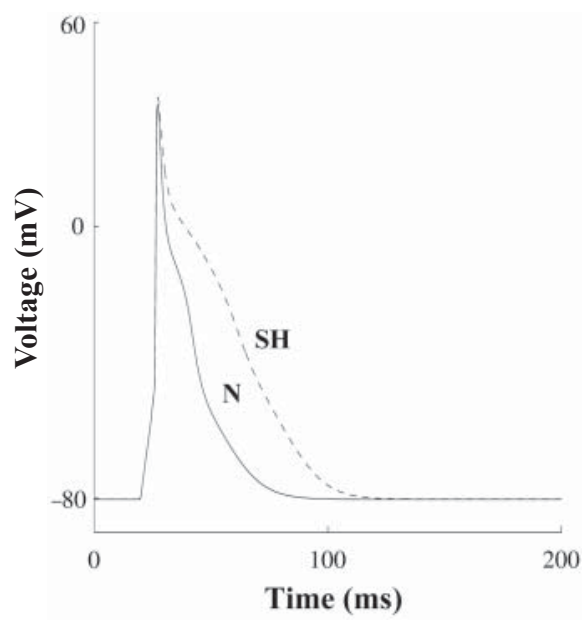

Figure 4 Model generated ventricular action potentials of the epicardialcells for the normal $(\mathrm{N})$ rat and spontaneously hypertensive $(\mathrm{SH})$ rat. 


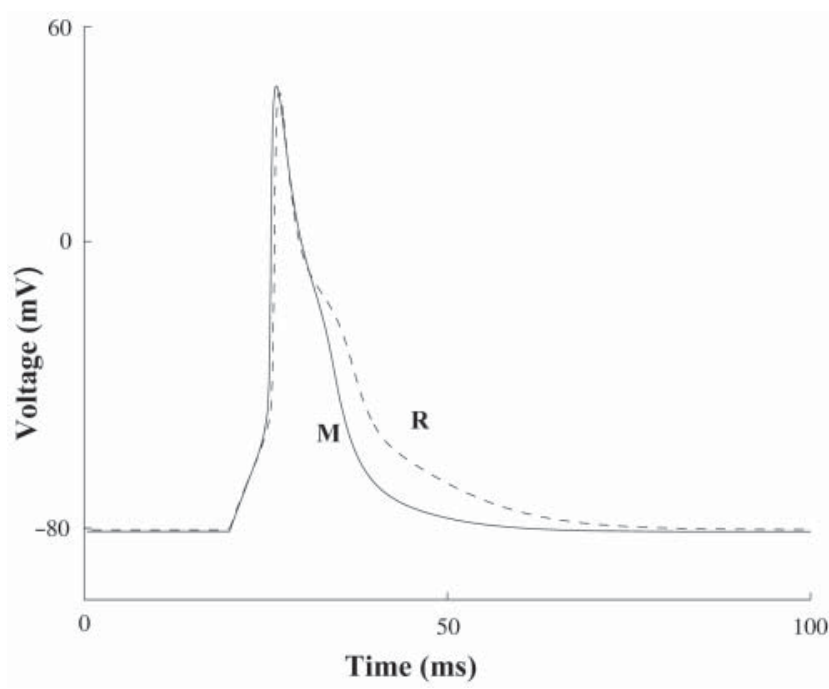

Figure 5 Simulated action potentials of the mouse left ventricular apex cell (M) and the rat right ventricular cell $(\mathrm{R})$.

\section{Impact of computational modelling in ventricular cells}

The impacts of the computational model development of ventricular bioelectric activity and the model-generated data in different disciplines of life sciences are summarised as follows:

1. Biophysics and physiology. The results of computational studies expand our knowledge of the living systems at the cellular level in electrophysiology.

2. Clinical physiology and medicine. The insights gained and conclusions derived from computational studies enhance our understanding of the biocomplexity of the heart and provide us with better knowledge to be used in the future in treatments for diseases in humans. We will also better understand the cardiac cells' responses to various pathophysiological states with simulation data.

3. Pharmacology. The differences in ventricular membrane ionic currents, especially outward $\mathrm{K}^{+}$ currents, in different species have very important practical implications. Different drugs are known to affect different ionic currents and change action potential waveforms in different mammalian heart preparations under various conditions of development, ageing and gender. A better understanding of the role of the ionic currents that control repolarisation in the ventricular myocytes obtained from various species including rat and mouse, as presented in this paper, will provide motivation and explanations for species differences in treatment and drug actions and also promote pharmacological research that may lead to the development of more specific drugs to be used in children and adults.

\section{Acknowledgements}

These computational research projects were funded by the Whitaker Foundation (PI: Dr SS Demir). The author acknowledges the contributions of her former students $\mathrm{S}$ Pandit, S Padmala and E Damaraju to these research projects.

\section{References}

Antzelevitch C, Yan G-X, Shimuzu W et al. 1999. Electrical heterogeneity, the ECG, and cardiac arrhythmias. In Zipes DP, Jalife J, eds. Cardiac electrophysiology: from cell to bedside. 3rd ed. Philadelphia: WB Saunders. p 222-38.

Barry DM, Xu H, Schuessler RB et al. 1998. Functional knockout of the transient outward current, long-QT syndrome, and cardiac remodeling in mice expressing a dominant-negative Kv4 alpha subunit. Circ Res, 83:560-7.

Beeler GW, Reuter H. 1977. Reconstruction of the action potential of ventricular myocardial fibres. J Physiol, 268:177-210.

Bers DM. 2001. Excitation-contraction coupling and cardiac contractile force. 2nd ed. The Netherlands: Kluwer Acad Publ.

Bouchard RA, Clark RB, Giles WR. 1995. Effects of action potential duration on excitation-contraction coupling in rat ventricular myocytes. Action potential voltage-clamp measurements. Circ Res, 76:790-801.

Bryant SM, Shipsey SJ, Hart G. 1999. Normal regional distribution of membrane current density in rat left ventricle is altered in catecholamine induced hypertrophy. Cardiovasc Res, 42:391-401.

Budden R, Detweiler DK, Zbinden G, eds. 1980. The rat electrocardiogram in pharmacology and toxicology. Oxford, NY: Pergamon Pr.

Cheung PH, Pugsley MK, Walker MJ. 1993. Arrhythmia models in the rat. J Pharmacol Toxicol Methods, 29:179-84.

Chien KR. 2000. Genomic circuits and the integrative biology of cardiac diseases. Nature, 407:227-32.

Chien KR. 2001. To Cre or not to Cre: the next generation of mouse models of human cardiac diseases. Circ Res, 88:546-9.

Clancy CE, Rudy Y. 1999. Linking a genetic defect to its cellular phenotype in a cardiac arrhythmia. Nature, 400:566-9.

Clark RB, Bouchard RA, Salinas-Stefanon E et al. 1993. Heterogeneity of action potential waveforms and potassium currents in rat ventricle. Cardiovasc Res, 27:1795-9.

Damaraju E. 2003. A computational model of action potential heterogeneity in adult mouse left ventricular myocytes [MSc thesis]. Memphis: University of Memphis.

Demir SS, O’Rourke B, Tomaselli GF et al. 1996. Action potential variation in canine ventricle: a modeling study. IEEE Comput Cardiol, 1996:221-4

Drouhard J, Roberge FA. 1987. Revised formulation of the HodgkinHuxley representation of the sodium current in cardiac cells. Comput Biomed Res, 20:333-50.

Fiset C, Clark RB, Larsen TS et al. 1997. A rapidly activating sustained $\mathrm{K}^{+}$current modulates repolarization and excitation-contraction coupling in adult mouse ventricle. J Physiol, 504:557-63.

Fox JJ, McHarg JL, Gilmour RF. 2002. Ionic mechanism of electrical alternans. Am J Physiol Heart Circ Physiol, 282:H516-30.

Franz WM, Mueller OJ, Hartong R et al. 1997. Transgenic animal models: new avenues in cardiovascular physiology. J Mol Med, 75:115-29. 
Gehrmann J, Berul CI. 2000. Cardiac electrophysiology in genetically engineered mice. J Cardiovasc Electrophysiol, 11:354-68.

Gussak I, Chaitman BR, Kopecky SL et al. 2000. Rapid ventricular repolarization in rodents: electrocardiographic manifestations, molecular mechanisms, and clinical insights. J Electrocardiol, 33: 159-70.

Hodgkin L, Huxley AF. 1952. A quantitative description of membrane current and its application to conduction and excitation in nerve. J Physiol, 117:500-44.

Jalife J, Morley GE, Vaidya D. 1999. Connexins and impulse propagation in the mouse heart. J Cardiovasc Electrophysiol, 10:1649-63.

Keating MT, Sanguinetti MC. 2001. Molecular and cellular mechanisms of cardiac arrhythmias. Cell, 104:569-80.

Kuo HC, Cheng CF, Clark RB et al. 2001. A defect in the Kv channelinteracting protein 2 (KChIP2) gene leads to a complete loss of $\mathrm{I}_{\text {to }}$ and confers susceptibility to ventricular tachycardia. Cell, 107: 801-13.

Lijnen P, Petrov V. 1999. Renin-angiotensin system, hypertrophy and gene expression in cardiac myocytes. J Mol Cell Cardiol, 31:949-70.

Luo CH, Rudy Y. 1991. A model of the ventricular cardiac action potential. Circ Res, 68:1501-26.

Luo CH, Rudy Y. 1994. A dynamic model of the cardiac ventricular action potential. I. Simulation of ionic currents and concentration changes. Circ Res, 74:1071-96.

Members of the Sicilian Gambit. 2001. New approaches to antiarrhythmic therapy. Part I: Emerging therapeutic applications of the cell biology of cardiac arrhythmias. Circulation, 104:2865-73.

Minamisawa S, Hoshijima M, Chu G et al. 1999. Chronic phospholambansarcoplasmic reticulum calcium ATPase interaction is the critical calcium cycling defect in dilated cardiomyopathy. Cell, 99:313-22.

Nerbonne JM. 2001. Molecular analysis of voltage-gated $\mathrm{K}^{+}$channel diversity and functioning in the mammalian heart. In Page E, Fozzard HA, Solaro RJ, eds. Handbook of physiology: the cardiovascular system. New York: Oxford Univ Pr. p 568-94.

Nerbonne JM, Nichols CG, Schwarz TL et al. 2001. Genetic manipulation of cardiac $\mathrm{K}^{+}$channel function in mice: what have we learned, and where do we go from here? Circ Res, 89:944-56.

Nguyen-Tran VT, Kubalak SW, Minamisawa S et al. 2000. A novel genetic pathway for sudden cardiac death via defects in the transition between ventricular and conduction system cell lineages. Cell, 102:671-82.

Noble D. 1962. A modification of the Hodgkin-Huxley equations applicable to Purkinje fibre action and pace-maker potentials. J Physiol, 160:317-52.

Noble D, Varghese A, Kohl P et al. 1998. Improved guinea-pig ventricular cell model incorporating a diadic space, $\mathrm{I}_{\mathrm{Kr}}$ and $\mathrm{I}_{\mathrm{Ks}}$, and length- and tension-dependent processess. Can J Cardiol, 14:123-34.

Nordin C. 1993. Computer model of membrane current and intracellular $\mathrm{Ca}^{2+}$ flux in the isolated guinea pig ventricular myocyte. Am J Physiol, 265:H2117-36.

Padmala S, Demir SS. 2003. A computational model of the ventricular action potential in adult spontaneously hypertensive rats. J Cardiovasc Electrophysiol, 14:990-5.

Pandit SV. 2002. Electrical activity in murine ventricular myocytes: simulation studies [PhD thesis]. Memphis: University of Memphis.

Pandit SV, Clark RB, Giles WR et al. 2001. A mathematical model of action potential heterogeneity in adult rat left ventricular myocytes. Biophys $J, 81: 3029-51$.
Pandit SV, Giles WR, Demir SS. 2003. A mathematical model of the electrophysiological alterations in rat ventricular myocytes in type-I diabetes. Biophys $J, 84: 832-41$.

Priebe L, Beuckelmann D. 1998. Simulation study of cellular electric properties in heart failure. Circ Res, 82:1206-23.

Puglisi JL, Bers DM. 2001. LabHEART: an interactive computer model of rabbit ventricular myocyte ion channels and Ca transport. Am J Physiol Cell Physiol, 281:C2049-60.

Qin D, Zhang ZH, Caref EB et al. 1996. Cellular and ionic basis of arrhythmias in postinfarction remodeled ventricular myocardium. Circ Res, 79:461-73.

Riemer TL, Sobie A, Tung L. 1998. Stretch-induced changes in arrhythmogenesis and excitability in experimentally based heart cell models. Am J Physiol, 275:H431-42.

Robbins J. 2000. Toward the new millennium. Annu Rev Physiol, 62: 961-3.

Rudy Y. 2000. From genome to physiome: integrative models of cardiac excitation. Ann Biomed Eng, 28:945-50.

Seidman JG, Seidman C. 2001. The genetic basis for cardiomyopathy: from mutation identification to mechanistic paradigms. Cell, 104: $557-67$.

Shimoni Y, Firek L, Severson D et al. 1994. Short-term diabetes alters $\mathrm{K}^{+}$ currents in rat ventricular myocytes. Circ Res, 74:620-8.

Shimoni Y, Light PE, French RJ. 1998. Altered ATP sensitivity of ATPdependent $\mathrm{K}^{+}$channels in diabetic rat hearts. Am J Physiol, 275: E568-76.

Shimoni Y, Severson D, Giles WR. 1995. Thyroid status and diabetes modulate regional differences in potassium currents in rat ventricle. $J$ Physiol, 488:673-88.

Spooner PM, Rosen MR, eds. 2000. Foundations of cardiac arrhythmias. 1st ed. New York: Marcel Dekker.

Ten Tusscher KH, Noble D, Noble PJ et al. 2004. A model for human ventricular tissue. Am J Physiol Heart Circ Physiol, 286:H1573-89.

Trepanier-Boulay V, St-Michel C, Tremblay A et al. 2001. Gender-based differences in cardiac repolarization in mouse ventricle. Circ Res, $89: 437-44$

Ward CA, Ma Z, Lee SS et al. 1997. Potassium currents in atrial and ventricular myocytes from a rat model of cirrhosis. Am J Physiol, 273:G537-44.

Watanabe T, Delbridge LM, Bustamante JO et al. 1983. Heterogeneity of the action potential in isolated rat ventricular myocytes and tissue. Circ Res, 52:280-90.

Winslow RL, Rice J, Jafri S et al. 1999. Mechanisms of altered excitationcontraction coupling in canine tachycardia-induced heart failure. II: Model studies. Circ Res, 84:571-86.

Winslow RL, Scollan DF, Holmes A et al. 2000. Electrophysiological modeling of cardiac ventricular function: from cell to organ. Annu Rev Biomed Eng, 2:119-55.

Xu H, Guo W, Nerbonne JM. 1999. Four kinetically distinct depolarizationactivated $\mathrm{K}^{+}$currents in adult mouse ventricular myocytes. $J$ Gen Physiol, 113:661-78.

Zeng J, Laurita K, Rosenbaum DS et al. 1995. Two components of the delayed rectifier $\mathrm{K}^{+}$current in ventricular myocytes of the guinea pig type: theoretical formulation and their role in repolarization. Circ Res, $77: 140-52$.

Zhou J, Jeron A, London B et al. 1998. Characterization of a slowly inactivating outward current in adult mouse ventricular myocytes. Circ Res, 83:806-14. 

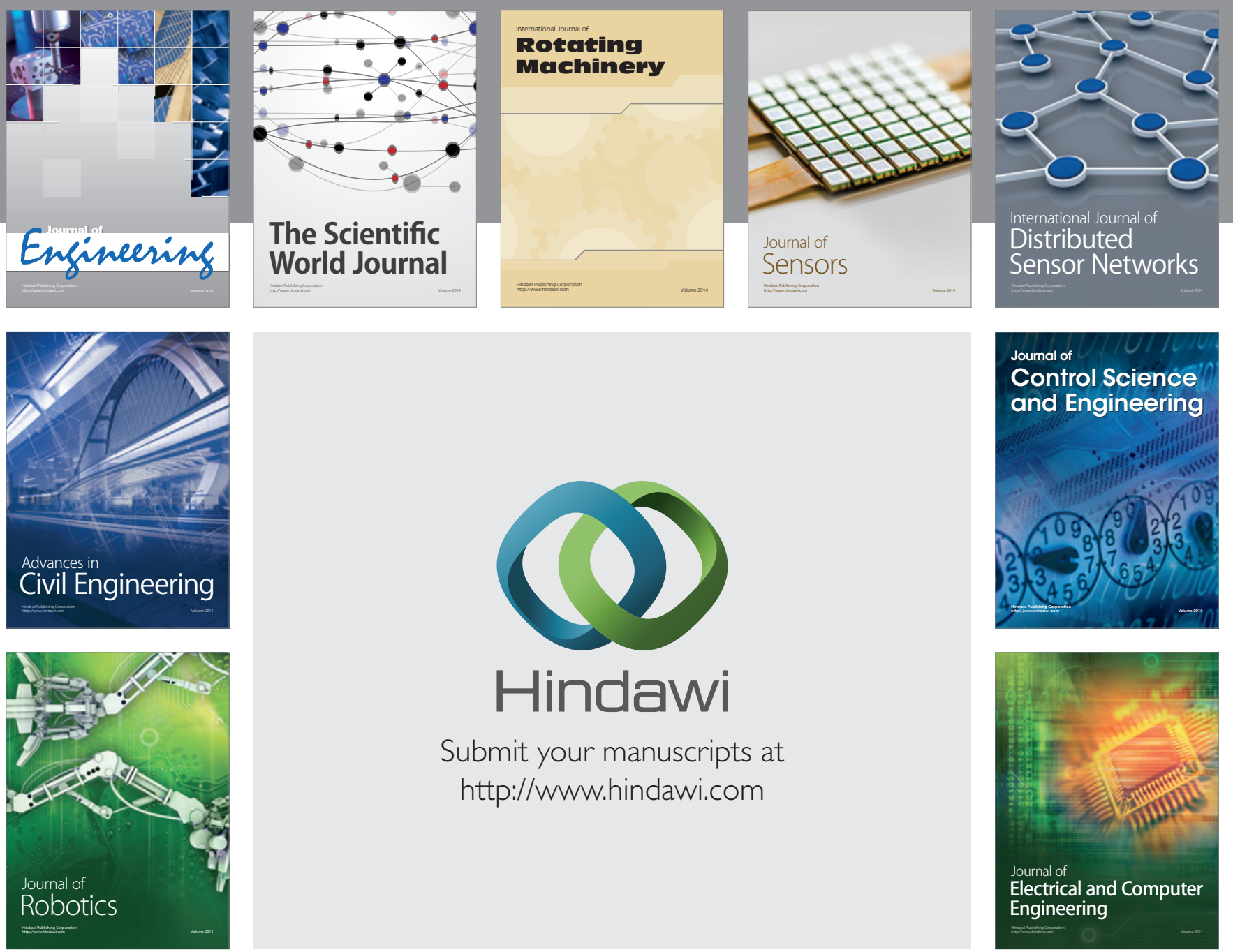

Submit your manuscripts at

http://www.hindawi.com
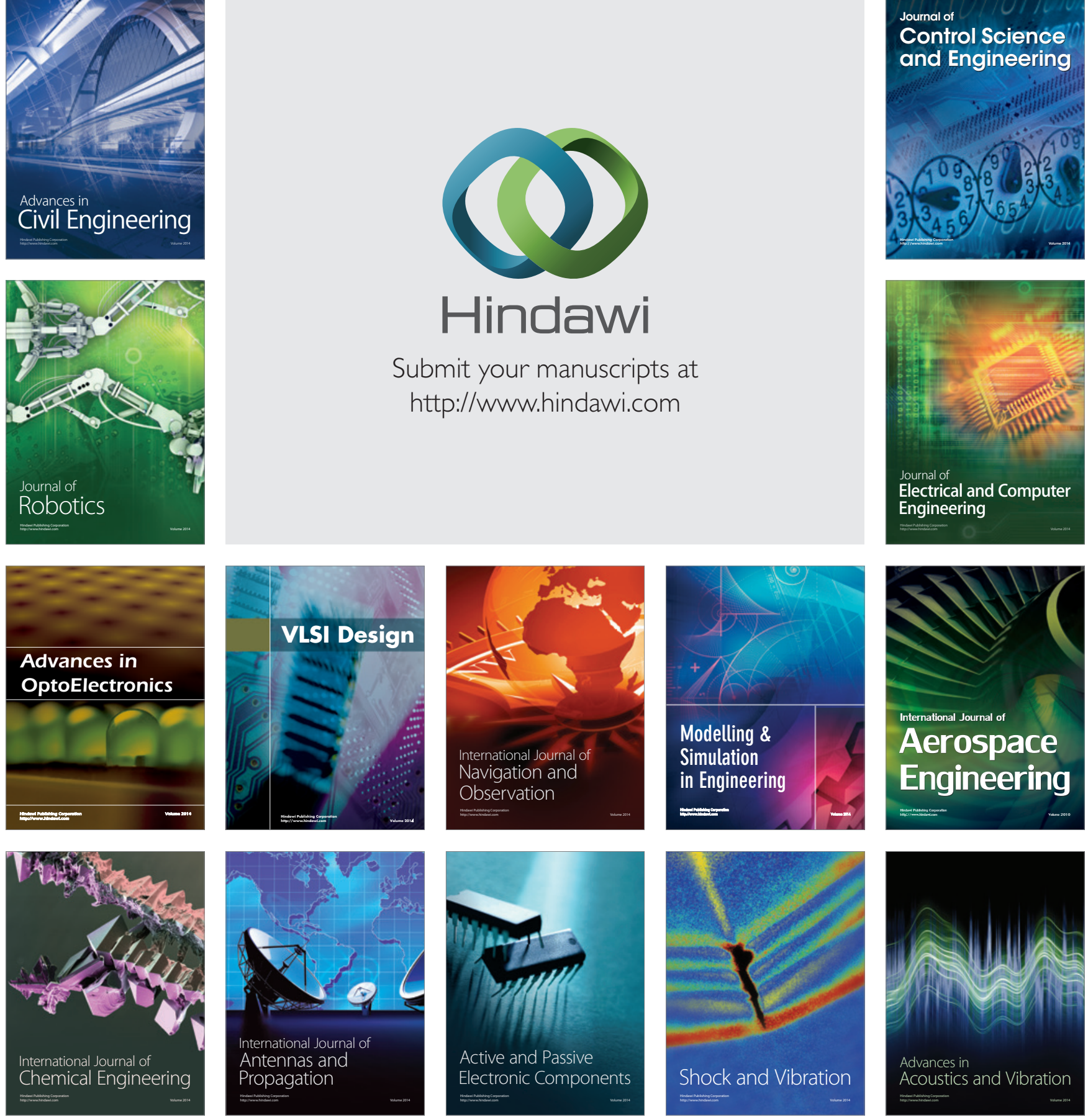